\title{
ZASTOSOWANIE KONCEPCJI ZARZĄDZANIA RYZYKIEM W OBSZARZE BEZPIECZEŃSTWA ŻYWNOŚCIOWEGO
}

\author{
Katarzyna Marzęda-Młynarska \\ Uniwersytet Marii Curie-Skłodowskiej w Lublinie \\ Wydział Politologii, Zakład Stosunków Międzynarodowych \\ adres, e-mail: marzedak@wp.pl
}

\begin{abstract}
Streszczenie. Celem artykułu jest analiza zastosowania zarządzania ryzykiem w obszarze bezpieczeństwa żywnościowego, traktowanego jako metoda jego zapewnienia, zarówno w sensie pozytywnym (tworzenie scenariuszy, systemów wczesnego ostrzegania), jak i negatywnym (ograniczanie ryzyka). Analiza została zorganizowana wokół dwóch problemów: głównych założeń koncepcji ryzyka i zarządzania ryzykiem oraz zastosowania zarządzania ryzykiem $\mathrm{w}$ obszarze bezpieczeństwa żywnościowego w trzech wymiarach: fizycznej i ekonomicznej dostępności oraz zdrowotnej jakości żywności. Przeprowadzona analiza daje podstawę do sformułowania następujących wniosków: po pierwsze, koncepcja zarządzania ryzykiem, znajduje szerokie zastosowanie na gruncie bezpieczeństwa żywnościowego. Po drugie, głównym motywem jej wykorzystanie jest dążenie do jego zapewnienia. Po trzecie, strategie, mechanizmy i instrumenty redukcji ryzyka, a także skala zastosowania i stopień instytucjonalizacji zarządzania ryzykiem różnią się w zależności od wymiaru bezpieczeństwa żywnościowego. Po czwarte, zarządzanie ryzykiem, ma charakter perspektywiczny i wykazuje dużą użyteczność, jako metoda eliminacji i ograniczania ryzyk, szczególnie współzmiennych, w obszarze bezpieczeństwa żywnościowego.
\end{abstract}

Słowa kluczowe: bezpieczeństwo żywnościowe, zarządzanie ryzykiem.

\section{WSTĘP}

Obserwowana na całym świecie z rosnącym niepokojem fala niekontrolowanej nielegalnej imigracji, stanowi przedsmak wielkich ruchów migracyjnych, czekających świat w najbliższej przyszłości. Prognozy ONZ, Banku Światowego oraz niezależnych ośrodków badawczych nie pozostawiają złudzeń, że głównymi zjawiskami zagrażającymi stabilności świata w drugiej połowie XXI wieku nie będą wyłącznie konflikty zbrojne, ale także brak dostępu do podstawowych dla egzystencji ludzkiej dóbr, takich jak woda czy 
żywność. ${ }^{1}$ Znajdują one swoje odzwierciedlenie m.in. w rosnących obawach o zapewnienie bezpieczeństwa żywnościowego (food security) zarówno w wymiarze globalnym jak i w poszczególnych państwach.

Pojęcie bezpieczeństwa żywnościowego weszło na stałe do języka międzynarodowego w latach 70. XX wieku za sprawą Światowej Konferencji Żywnościowej ${ }^{2}$, jednak dopiero koniec XX wieku wyznaczył nową perspektywę jego interpretacji. Złożyło się na to wiele czynników. Po pierwsze, znacznie rozszerzył się zakres zjawisk go warunkujących, na które obok sił natury, składają się również siły ekonomiczne, społeczne, a także nowe technologie i wiedza. ${ }^{3}$ Po drugie, radykalnej zmianie uległ sposób jego rozumienia. $\mathrm{O}$ ile pierwotnie odnoszono je wyłącznie do problemów związanych z zaopatrzeniem, traktując jako instrument budowy systemu ochrony producentów i konsumentów przed niekontrolowanymi zmianami cen artykułów rolnych, ${ }^{4}$ o tyle współcześnie łączy w sobie wiele różnorodnych problemów, począwszy od rolnictwa, przez handel, zapasy, ceny żywności, poziom dochodów na technologiach i bezpieczeństwie produkcji kończąc.

Przyjmując za punkt wyjścia definicję Organizacji NZ ds. Wyżywienia i Rolnictwa (FAO) z 1996 roku, bezpieczeństwo żywnościowe można sprowadzić do trzech wymiarów: 1) fizycznej dostępności żywności, oznaczającej jej ‘fizyczne istnienie' w każdym czasie bez względu na źródło pochodzenia, 2) ekonomicznej dostępności żywności, oznaczającej, że każda jednostka i gospodarstwo domowe posiada wystarczające zasoby pozwalające nabyć żywność w odpowiedniej ilości i jakości oraz 3) zdrowotnej jakości żywności, zapewniającej 'zdrowe i aktywne życie. ${ }^{5} \mathrm{Na}$ tak rozumiane bezpieczeństwo żywnościowe składa się zatem gęsta sieć powiązanych ze sobą i nawzajem oddziałujących zjawisk, a jego zapewnienie wymaga zastosowania zróżnicowanych metod i środków.

Celem artykułu jest analiza zastosowania zarządzania ryzykiem w obszarze bezpieczeństwa żywnościowego, traktowanego jako metoda jego zapewnienia zarówno w sensie pozytywnym (tworzenie scenariuszy, systemów wczesnego ostrzegania), jak i negatywnym (ograniczanie ryzyka). Koncepcja ta kładzie nacisk na rozpoznawanie istniejących zagrożeń, ich kontrolowanie i przygotowanie się na ewentualne negatywne skutki. Jej istotą jest zapobieganie, w odróżnieniu

1 World Bank, Food Price Watch, Year 5, Issue 17, May 2014, URL: http://www.worldbank.org/content/dam/Worldbank/document/Poverty\%20documents/FPW_May\%202014_final. pdf, [dostęp: 12.07.2015]; H. -J. Brinkman, C.S. Hendrix, Food Insecurity and Violent Conflict: Causes, Consequences and Addressing the Challenges, WFP Occasional Paper no 24, July 2011, World Economic Forum, Global Risks 2016. Tenth Edition, URL: http://www3.weforum.org/docs/ WEF_Global_Risks_2015_Report15.pdf, [dostęp: 12.07.2015]. 2007.

${ }^{2}$ Szerzej: D. J. Shaw, World Food Security. A History since 1945, Basingstoke-New York

3 Szerzej: K. Marzęda-Młynarska, Globalne zarządzanie bezpieczeństwem żywnościowym na przełomie XX i XXI wieku, Wydawnictwo UMCS, Lublin 2014.

4 D. J. Shaw, World Food Security, op. cit., s. 5.

5 FAO, Rome Declaration on World Food Security and World Food Summit Plan of Action, World Food Summit 13-17 November 1996, Rome. 
od reagowania, na już zaistniałe zjawiska, co oznacza, że uniknięcie wspomnianego powyżej negatywnego scenariusza migracyjnego zależeć będzie między innymi od właściwego rozpoznania i wyeliminowania czynników zagrażających egzystencji milionów potencjalnych migrantów.

Ze względu na konieczność zachowania jasności wywodu w strukturze artykułu uwzględnione zostaną jedynie wybrane wątki. Analizę zorganizowano wokół dwóch problemów: głównych założeń koncepcji ryzyka i zarządzania ryzykiem oraz zastosowania zarządzania ryzykiem $\mathrm{w}$ obszarze bezpieczeństwa żywnościowego. W pierwszej części przedmiotem rozważań będzie koncepcja zarządzania ryzykiem w ujęciu teoretycznym, jej ujęcia, etapy. W drugiej omówione zostaną praktyczne sposoby wykorzystania zarządzania ryzykiem w trzech wyodrębnionych powyżej wymiarach: fizycznej i ekonomicznej dostępności oraz zdrowotnej jakości żywności, ${ }^{6}$ poprzedzone rozważaniami na temat sposobów jego rozumienia i zastosowania na gruncie bezpieczeństwa żywnościowego

\section{RYZYKO I ZARZĄDZANIE RYZYKIEM - ZAŁOŻENIA WSTĘPNE}

W coraz bardziej skomplikowanym środowisku decyzyjnym na znaczeniu zyskują metody oparte na antycypowaniu potencjalnie negatywnych zjawisk i ich konsekwencji. Jedną z nich jest analiza ryzyka. Przeniesiona na sferę polityki opiera się na tej samej logice co ocena ryzyka w ekonomii, mająca na celu oszacowanie kosztów, które mogą przybierać zarówno formę ilościową - np. straty finansowe, jak i jakościową - np. obniżenie sprawności działania danej organizacji.

Ryzyko jest kluczowym pojęciem koncepcji zarządzania ryzykiem. W literaturze przedmiotu funkcjonuje wiele jego definicji. Celem artykułu nie jest jednak ich dogłębna analiza, a jedynie pokazanie, że na gruncie polityki najczęściej związane jest z podejmowaniem decyzji i ich implementacją. $Z$ tego względu zostaną zaprezentowane dwie. Pierwsza, Anny Moraczewskiej osadza ryzyko w obszarze stosunków międzynarodowych (SM) i traktuje je jako funkcję zagrożenia dla podmiotu SM, jego wrażliwości i wpływu na ten podmiot, gdzie zagrożenie jest zjawiskiem powstałym w wyniku występowania określonej siły o istotnym znaczeniu dla bezpieczeństwa czy też ciągłości podmiotu, wrażliwość - jego zdolnością do adaptacji i minimalizowania negatywnych skutków ryzyka, a wpływ prawdopodobnymi skutkami. ${ }^{7}$

Druga definicja, autorstwa Elizabeth Fisher ma bardziej praktyczny charakter, bowiem osadza ryzyko w sferze polityki wewnętrznej państwa, traktując je jako sytuację lub zdarzenie, w którym jakaś wartość ogólnoludzka, łącznie z samą jednostką ludzką, zostaje wystawiona na niepewność, podobnie jak niepewne są

6 Szerzej patrz: K. Marzęda-Młynarska, Globalne zarządzanie, op. cit.

7 A. Moraczewska, Zarzadzanie ryzykiem na zewnętrznych granicach państw czlonkowskich Unii Europejskiej, w publikacji, Wydawnictwo UMCS, Lublin 2016. 
efekty tego zdarzenia lub sytuacji. ${ }^{8}$ Tak rozumiane ryzyko znacząco wpływa na sposób funkcjonowania państwa w czterech obszarach: działaniach administracji publicznej, działalności regulacyjnej, egzekwowaniu prawa, oraz roli i znaczenia państwa, jako aktora w sferze publicznej i prywatnej. ${ }^{9}$

Obie definicje, osadzające ryzyko w kontekście polityki, sprawdzają je do procesu decyzyjnego, służącego jego antycypowaniu, unikaniu i kompensowaniu. ${ }^{10} \mathrm{~W}$ obu, także jego identyfikacja jest następstwem procesu myślowego, którego podstawę stanowi obiektywna wiedza. Oznacza to, że kategoria ryzyka nierozerwalnie łączy się z gromadzeniem wiedzy - jej analizą, kwantyfikacją i obiektywizacją, która następnie stanowi podstawę podejmowanych decyzji.

Przedstawione definicje wskazują także, że z kategorią ryzyka w polityce wiążą się dwa procesy: szacowanie (ocena) ryzyka (ang. risk assessment) i 'administrowanie' ryzykiem (ang. risk management) - określane mianem narzędzi analitycznych (ang. analytical tools). ${ }^{11}$ Co ważne w sensie podmiotowym oba procesy mogą przebiegać niezależnie. Szacowanie ryzyka jest bowiem domeną środowisk naukowych oraz niezależnych ekspertów, administrowanie ryzykiem - decydentów.

Znając sposób rozumienia kategorii ryzyka wyjaśnienia wymaga pojęcie zarządzania ryzykiem. W języku angielskim mamy do czynienia z funkcjonowaniem dwóch odrębnych pojęć: risk management ${ }^{12} \mathrm{i}$ risk governance. ${ }^{13} \mathrm{~W}$ języku polskim różnica ta jest trudna do uchwycenia, dlatego wymaga krótkiego komentarza. Risk management traktowane jest zazwyczaj jako druga faza risk governance, następująca po risk assessment. ${ }^{14}$ Risk management ma charakter techniczny i polega na tworzeniu i wyborze alternatywnych wariantów decyzji w oparciu o przeprowadzoną ocenę ryzyka. Dla podkreślenia jego specyfiki przetłumaczono je jako 'administrowanie' a nie 'zarządzanie'. Risk governance - thumaczone jako zarządzanie - ma charakter holistyczny i dotyczy rozpoznawania rodzaju ryzyka, jego pomiaru i kontrolowania, a zatem łączy w sobie oba procesy - gromadzenie i przetwarzanie danych oraz tworzenie alternatywnych wariantów decyzji i ich podejmowanie.

Zastosowanie tego rozgraniczenia odzwierciedla zmiany zachodzące w sposobie podejmowania decyzji zarówno na szczeblu państw jak i międzynarodo-

${ }^{8}$ E. Fisher, Risk and Governance, [w:] Oxford Handbook of Governance, red. D. Levi-Faur, Oxford University Press, Oxford 2012, s. 418.

${ }^{9}$ Ibidem, s. 419.

${ }^{10}$ Por. T. T. Kaczmarek, Ryzyko i zarządzanie ryzykiem. Ujęcie interdyscyplinarne, Difin, Warszawa 2006, s. 68.

${ }^{11}$ E. Fisher, op. cit., s. 420.

${ }^{12}$ L. N. Jackson, M. Jansen, Risk assessment in the international food safety policy arena. Can the multilateral institutions encourage unbiased outcomes?, "Food Policy" 2010, vol. 3, issue 6 , s. 538-547.

${ }^{13}$ E. Fisher, op. cit., s. 417-428.

${ }^{14}$ L. N. Jackson, M. Jansen, op. cit. 
wym. O jego istocie, decydują bowiem takie elementy jak: instytucje i aktorzy zlokalizowani zarówno na poziomie państw jak i ponad nimi, zacierające się obowiązki w rozwiązywaniu problemów społecznych i gospodarczych, specyfika zależności pomiędzy instytucjami zaangażowanymi we wspólne działania oraz nowe narzędzia $i$ techniki zarządzania. ${ }^{15} \mathrm{~W}$ praktyce, ze względu na istniejące funkcjonalne rozgraniczenie fazy analitycznej i decyzyjnej, w zarządzaniu ryzykiem uczestniczy coraz większa grupa podmiotów, zarówno prywatnych jak i publicznych, a także zwiększeniu ulega zakres dostępnych sposobów zarządzania i rozumienia problemów będących ich przedmiotem.

Zarządzanie ryzykiem można rozpatrywać w trzech ujęciach, umownie nazwanych funkcjonalnym, podmiotowym oraz operacyjnym. W ujęciu funkcjonalnym obejmuje ono dwie fazy: analityczną i decyzyjną. W fazie analitycznej dokonuje się identyfikacji zagrożenia i jego możliwych konsekwencji. Przebiega ona zazwyczaj w czterech etapach, na które składają się identyfikacja ryzyka, jego charakterystyka, ocena zakresu i wskazanie możliwych skutków. W fazie decyzyjnej - decyduje się, jak zidentyfikowane ryzyko ograniczyć i jak zabezpieczyć się przed jego ewentualnymi skutkami. ${ }^{16}$

W ujęciu podmiotowym zarząazanie ryzykiem rozpatrywane jest z perspektywy kategorii aktorów uczestniczących, których umownie można podzielić na dwie grupy: dostarczycieli wiedzy - ekspertów, naukowców, ośrodki badawcze, prywatne firmy zajmujące się oceną ryzyka, oraz decydentów - państwa, ich organy i instytucje oraz organizacje międzynarodowe, ${ }^{17} \mathrm{którzy}$ podejmują decyzje w sferze ryzyka.

W ujęciu operacyjnym, zarządzanie ryzykiem rozpatrywane jest natomiast z perspektywy strategii, mechanizmów, narzędzi i instrumentów kompensowania ryzyka, obejmujących budowę scenariuszy, przygotowanie ćwiczeń kryzysowych, tworzenie systemów wczesnego ostrzegania, indeksów ryzyka czy map wrażliwości. ${ }^{18}$

\section{RYZYKO I ZARZĄDZANIE RYZYKIEM NA GRUNCIE BEZPIECZEŃSTWA ŻYWNOŚCIOWEGO}

Z punktu widzenia przedmiotu rozważań kluczowe znaczenie ma ujęcie operacyjne, prezentowane, między innymi, przez autorów opracowania Global Risks 2015. Jego analiza wymaga jednak wyjaśnienia czym jest ryzyko i jak jest rozumiane na gruncie bezpieczeństwa żywnościowego. W opublikowanym

${ }^{15}$ G. Stoker, Governance as theory: five propositions, „International Social Science Journal” 1998, vol. 50, issue 155, s. 17-28.

${ }^{16}$ L. N. Jackson, M. Jansen, op. cit., s. 540-541.

${ }^{17}$ Ibidem. 539.

${ }^{18}$ Por. World Economic Forum, Global Risks 2015. Tenth Edition, Geneva 2015, URL: http:// www3.weforum.org/docs/WEF_Global_Risks_2015_Report15.pdf, [dostęp: 13.07.2015]. 
w 2009 roku przez Światowy Program Żywnościowy raporcie zatytułowanym Hunger and Markets zdefiniowano je jako „prawdopodobieństwo braku bezpieczeństwa żywnościowego będącego wynikiem interakcji pomiędzy zagrożeniami naturalnymi i wywołanymi przez człowieka a poziomem wrażliwości". ${ }^{19}$ Gdzie pod pojęciem zagrożenia rozumiano ,prawdopodobieństwo szkodliwego zjawiska w danym okresie lub na danym obszarze" natomiast pod pojęciem poziomu wrażliwości na brak bezpieczeństwa żywnościowego - ,funkcję ekspozycji gospodarstw domowych na zagrożenie i ich zdolności do ograniczenia lub minimalizowania jego skutków". ${ }^{20}$

Istniejące w obszarze bezpieczeństwa żywnościowego ryzyka analizowane są z różnych perspektyw i rozpatrywane na różnych poziomach. W literaturze przedmiotu dzieli się je na globalne, regionalne, narodowe, lokalne, środowiskowe, rynkowe, polityczne i społeczne, ale także rozpoznane i nierozpoznane oraz występujące na poziomie makro i mikro czy współzmienne i niezależne ${ }^{21}$ (tabela 1). Jak jednak zauważa Joachim von Braun - wieloletni dyrektor generalny Międzynarodowego Instytutu Badania Polityki Żywnościowej (International Food Policy Research Institute), o ile problem braku bezpieczeństwa żywnościowego był znany w przeszłości, o tyle globalne ryzyka, mające potencjalnie największy wpływ na jego poziom nasilają się i jest wielce prawdopodobne, że tendencja ta utrzyma się w przyszłości w największym stopniu oddziałując na poziom bezpieczeństwa żywnościowego na świecie i w poszczególnych państwach. ${ }^{22}$ Autor zalicza do nich wysokie i zmienne ceny żywności, kryzysy finansowe i ekonomiczne, zmiany klimatu oraz epidemie dotykające ludzi, zwierzeta i rośliny. ${ }^{23}$ Dodatkowo ich specyfika powoduje, że ryzyka stają się współzmienne (ang. covariate risks), czyli w dłuższej perspektywie czasu mogą prowokować inne ryzyka, w tym polityczne i społeczne, takie jak zamieszki, masowe migracje, destabilizacja rządów, konflikty.

Wiedząc czym jest ryzyko w obszarze bezpieczeństwa żywnościowego i jakie ryzyka w największym stopniu oddziałują na jego poziom należy postawić pytanie o sposoby zarządzania nim, a w szczególności o strategie, mechanizmy, narzędzia i instrumenty wykorzystywane w jego ramach.

W zależności od wymiaru, istniejące w literaturze przedmiotu z zakresu bezpieczeństwa żywnościowego strategie można sprowadzić do następujących: 1/akceptacji ryzyka, 2/unikania lub eliminowania ryzyka, 3/przeniesienia ryzyka oraz 4/ kontroli ryzyka. Akceptacja ryzyka charakterystyczna jest dla fizycznej dostępności żywności i ma związek ze środowiskowymi uwarunkowaniami pro-

${ }^{19}$ World Hunger Series. Hunger and Markets, WFP, London-Rome 2009, s. 96.

${ }^{20}$ Ibidem.

${ }^{21}$ C. Miller, Risk Mitigation and Management for Agricultural Investment. Investment and Resource Mobilization, EasyPol Module 155, FAO Policy Learning Programme, FAO 2008.

${ }^{22}$ J. von Braun, Food-Security Risks Must be Comprehensively Addressed, "IFPRI Annual Report Essay" 2008-2009, s. 3.

${ }^{23}$ Ibidem. 
Tab. 1. Ryzyka w obszarze bezpieczeństwa żywnościowego

\begin{tabular}{|c|c|c|c|}
\hline \multicolumn{4}{|c|}{ Kryteria podziału } \\
\hline zakres & przedmiot & poziom & świadomość \\
\hline $\begin{array}{l}\text { - globalne (zmiany } \\
\text { klimatu, wysokie } \\
\text { i zmienne ceny } \\
\text { żywności, epidemie, } \\
\text { kryzysy gospodarcze } \\
\text { i finansowe) } \\
\text { - regionalne (położenie } \\
\text { geograficzne, } \\
\text { ukształtowanie } \\
\text { terenu, klimat, } \\
\text { opady, dostępność } \\
\text { ziem uprawnych, } \\
\text { demografia) } \\
\text { - narodowe (liczba } \\
\text { ludności, sytuacja } \\
\text { ekonomiczna, } \\
\text { dostępność wody i ziem } \\
\text { upranych, stabilność } \\
\text { polityczna) } \\
\text { - lokalne (dostęp do } \\
\text { rynków, uzależnienie } \\
\text { od opadów, dostęp do } \\
\text { infrastruktury, żyzność } \\
\text { gleb) }\end{array}$ & $\begin{array}{l}\text { - środowiskowe } \\
\text { (zmiany: ekstremalne } \\
\text { zjawiska pogodowe, } \\
\text { susze, powodzie, } \\
\text { deficyt wody, dostęp } \\
\text { do ziemi uprawnej) } \\
\text { - polityczne (kryzysy } \\
\text { polityczne, konflikty, } \\
\text { zamieszki, polityka } \\
\text { żywnościowa) } \\
\text { - rynkowe (wysokie } \\
\text { ceny żywności, } \\
\text { polityka eksporterów } \\
\text { żywności, terms } \\
\text { of trade, dostęp do } \\
\text { rynków, struktura } \\
\text { rynku) } \\
\text { - społeczne } \\
\text { (demografia, wiek, } \\
\text { płeć, religia, kultura, } \\
\text { ubóstwo) } \\
\text { - niezależne } \\
\text { - współzmienne }\end{array}$ & $\begin{array}{l}\text { - makro (uzależnienie } \\
\text { od importu żywności, } \\
\text { polityki społeczne, } \\
\text { systemy zabezpieczeń } \\
\text { społecznych) } \\
\text { - mikro (niski } \\
\text { i niestabilny dochód, } \\
\text { wysokie bezrobocie, } \\
\text { brak zabezpieczeń } \\
\text { społecznych, choroby, } \\
\text { wypadki, śmierć } \\
\text { członków rodziny) }\end{array}$ & $\begin{array}{l}\text { - rozpoznane } \\
\text { - nierozpoznane }\end{array}$ \\
\hline
\end{tabular}

Źródło: opracowanie własne na podstawie: K. Marzęda-Młynarska, Globalne zarządzanie bezpieczeństwem żywnościowym na przełomie XX i XXI wieku, Wyd. UMCS, Lublin 2014; J. von Braun, Food-Security Risks Must be Comprehensively Addressed, "IFPRI Annual Report Essay" 2008-2009; WFP, Comprehensive Food Security \& Vulnerability Analysis Guidelines, January 2009.

dukcji żywności, takimi jak klimat, pogoda, dostępność wody czy ziemi uprawnej, na które oddziałują negatywne zjawiska (ekstremalne zjawiska pogodowe, powodzie, susze), wobec których człowiek nadal pozostaje bezradny. Istota strategii akceptacji sprowadza się do adaptowania do istniejącego ryzyka, poprzez tworzenie i implementację polityk minimalizujących jego negatywny wpływ. Unikanie i eliminowanie ryzyka charakterystyczne jest dla ekonomicznej dostępności żywności oraz zdrowotnej jakości żywności, gdzie wykorzystując mechanizmy rynkowe (ekonomiczna dostępność), czy istniejące procedury (zdrowotna jakość żywności) można skutecznie unikać lub eliminować ryzyka. Przeniesienie ryzyka wykorzystywane jest zarówno w odniesieniu do fizycznej, jak i ekonomicznej dostępności żywności. W strategii tej chodzi bowiem o zastosowanie ubezpieczeń, a więc porozumień, w ramach których ktoś inny przyjmuje ryzyko w zamian za określoną premię lub instrumentów rynkowych służących eksternalizacji ryzyka (opcje). Kontrola ryzyka to strategia wykorzystywana we wszystkich trzech wymiarach bezpieczeństwa żywnościowego. W jej ramach zastosowanie ma szereg 
instrumentów, wśród których na szczególną uwagę zasługują indeksy bezpieczeństwa żywnościowego, mapy wrażliwości, czy systemy wczesnego ostrzegania. ${ }^{24}$

W przypadku mechanizmów zarządzania ryzykiem w obszarze bezpieczeństwa żywnościowego większość badaczy uznaje, że ze względu na rosnący wpływ współzmiennych ryzyk na poziomie globalnym, kluczowe znaczenie dla jego zapewnienia będą miały przede wszystkim mechanizmy oparte na wzmocnieniu i rozbudowie systemów informacyjnych, w tym systemów wczesnego ostrzegania, wzmocnieniu i tworzeniu systemów usług finansowych w obszarach wiejskich, rozbudowie systemów ubezpieczeń rolnych, w tym ubezpieczeń od skutków zmian klimatu, a także oparte na rynkowych mechanizmach instrumenty kompensacji zmienności cen żywności, budowa systemów zabezpieczeń społecznych oraz tworzenie planów i ćwiczeń na wypadek katastrof naturalnych. ${ }^{25}$

Duża różnorodność charakteryzuje instrumenty zarządzania ryzykiem w obszarze bezpieczeństwa żywnościowego, co warunkują jego wymiary. Nie mniej jednak ze względu na rosnące znacznie czynników współzmiennych wzrasta rola instrumentów o charakterze globalnym, dostępnych dla szerokiego grona odbiorców (rządy państw, organizacje międzynarodowe, NGOs), obejmujących wszystkie wymiary bezpieczeństwa żywnościowego. Funkcję taką pełnią: Indeks Ryzyka w obszarze Bezpieczeństwa Żywnościowego, Globalny Indeks Wrażliwości, Globalny System Informacji i Wczesnego Ostrzegania w obszarze Wyżywienia i Rolnictwa (Global Information and Early Warning System on Food and Agriculture) oraz Analiza Wrażliwości i Mapowanie.

Indeks ryzyka w obszarze bezpieczeństwa żywnościowego (Food Security Risk Index) jest jednym z wielu indeksów sporządzanych przez prywatną firmę Maplecrof ${ }^{26}{ }^{2}$ ajmującą się analizą ryzyka. Jego celem jest szacowanie ryzyka braku bezpieczeństwa żywnościowego na podstawie ilościowej oceny fizycznej i ekonomicznej dostępności żywności, stabilności systemów produkcji żywności oraz stanu odżywienia w poszczególnych państwach. Indeks uwzględnia 18 kluczowych wskaźników, które razem tworzą cztery podindeksy: bieżący stan odżywienia i zdrowia populacji, dostępność żywności, stabilność dostępności oraz dostęp do zapasów. Wyniki analizy prezentowane są w formie interaktywnej mapy świata (ryc.1), na której państwa klasyfikowane są według czterech kategorii ryzyka: ekstremalne, wysokie, średnie, niskie. Mapa wskazuje również główne 'ogniska' braku bezpieczeństwa żywnościowego, czyli państwa klasyfikowane w grupie ekstremalnego ryzyka - głównie państwa Afryki Subsaharyskiej, ale także Haiti, Afganistan, Bangladesz oraz Korea Północna. Indeks skierowany jest do rządów państw, organizacji

${ }^{24}$ Szerzej na ten temat: C. Miller, op. cit.; Risk Management and Food Safety, "FAO Food and Nutrition Paper" no 65, Report of Joint FAO/WHO Consultation, Rome, Italy 27-31 June, January 1997; FAO, Resilient Livelihoods. Disaster Risk Reduction for Food and Nutrition Security, 2013 Edition, FAO, Rome.

${ }^{25}$ Szerzej: J. von Braun, op. cit., C. Miller, op. cit.

${ }^{26}$ Więcej na temat firmy i oferowanych przez nią usług z zakresu analizy ryzyka na stronie: URL: $<$ https://maplecroft.com>. 
pozarządowych i biznesu, jako instrument identyfikacji i kontroli ryzyka braku bezpieczeństwa żywnościowego w państwach podatnych na klęski głodu i niepokoje społeczne wynikające z braku żywności i wahań cen. ${ }^{27}$

Ryc. 1. Indeks Ryzyka Bezpieczeństwa Żywnościowego 2013

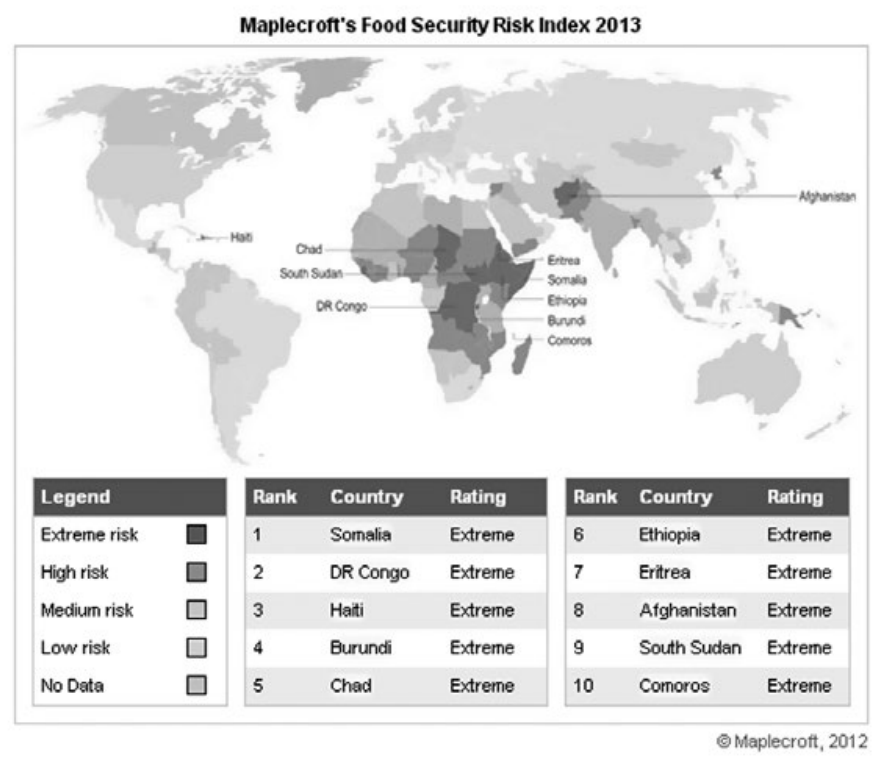

Źródło: Maplecroft 2012, URL: <https://maplecroft.com>.

Drugi ze wspomnianych instrumentów - Globalny Indeks Wrażliwości (Global Vulnerability Index) stworzony i wykorzystywany przez Światowy Program Żywnościowy łączy informacje dotyczące wrażliwości poszczególnych państw na brak bezpieczeństwa żywnościowego z wysokimi cenami żywności. Indeks składa się z pięciu podindeksów: zdolności państw do reagowania, sytuacji społeczno-gospodarczej, wrażliwości na brak bezpieczeństwa żywnościowego dzieci (niedowaga, zakażenie HIV/AIDS) oraz ubóstwo i dystrybucja dochodów, poziom odżywienia. ${ }^{28}$

Trzeci instrument - Globalny System Informacji i Wczesnego Ostrzegania w obszarze Wyżywienia i Rolnictwa - GIEWS to globalny system informacji i monitorowania bezpieczeństwa żywnościowego na świecie, stworzony w 1975 roku w następstwie Światowej Konferencji Żywnościowej z 1974 roku. Jego zadaniem jest dostarczanie najbardziej aktualnych i dokładnych informacji dotyczących wszystkich wymiarów bezpieczeństwa żywnościowego. Gromadzi dane dotyczące

${ }^{27}$ Informacje pochodzą ze strony firmy Maplecroft: URL: https://maplecroft.com/about/ news/food_security_risk_index_2013.html, [dostęp: 30.07.2015].

${ }^{28}$ World Hunger Series, op. cit., s. 100. Interaktywne mapy ilustrujące Globalny Indeks Wrażliwości dostępne są na stronie WFP: http://geonode.wfp.org/layers/geonode:global_vulnerability, [dostęp 30.07.2015] 
upraw, popytu i podaży zbóż, cen, sytuacji rynkowej, służące wczesnemu wykrywaniu ryzyka kryzysów żywnościowych. Korzystają z niego rządy państw, organizacje międzynarodowe, NGOs, sektor prywatny a także jednostki naukowo-badawcze. ${ }^{29}$

Podobnym celom służy Analiza Wrażliwości i Mapowanie stanowiąca podstawowy system wczesnego ostrzegania, stworzony w 1994 roku wykorzystywany przez WFP do planowania i zarządzania działaniami interwencyjnymi w obszarze bezpieczeństwa żywnościowego. Jego funkcjonowanie opiera się na współpracy kilkuset ekspertów z zakresu analizy bezpieczeństwa żywnościowego rozsianych na całym świecie, obejmującej ocenę, badania, analizy, monitoring, rzecznictwo i budowanie zdolności. Gromadzi informacje dotyczące kryzysów, rynków, stanu bezpieczeństwa żywnościowego, poziomu ryzyka i na ich podstawie tworzy mapy obrazujące poziom wrażliwości poszczególnych regionów. Korzystają z niego rządy państw, donatorzy, organizacje globalne i regionalne, NGOs, a także ośrodki naukowo-badawcze i media. ${ }^{30}$

Nie ulega zatem wątpliwości, że koncepcja zarządzania ryzykiem znajduje szerokie zastosowanie w obszarze bezpieczeństwa żywnościowego, co stanowi dobry wstęp do analizy jej zastosowań w poszczególnych wymiarach.

\section{ZARZĄDZANIE RYZYKIEM W OBSZARZE FIZYCZNEJ DOSTĘPNOŚCI ŻYWNOŚCI}

Fizyczna dostępność żywności oznacza jej 'fizyczne istnienie' bez względu na źródło pochodzenia. ${ }^{31}$ Jej wyznacznikami są produkcja, sprzedaż oraz wielkość zapasów. W najbardziej podstawowym znaczeniu oznacza relację pomiędzy zaopatrzeniem w żywność a wielkością populacji. ${ }^{32}$ Problem produkcji odpowiedniej ilości żywności można rozpatrywać w dwóch wymiarach. Po pierwsze, w wymiarze globalnym i tu największe wyzwanie dla zwiększenia produkcji stanowią bariery biofizyczne, po drugie, w wymiarze narodowym, czyli w odniesieniu do poszczególnych państw. Tu problemem jest podniesienie zdolności produkcyjnych rolnictwa. ${ }^{33}$ Ważnymi wyznacznikami fizycznej dostępności żywności są także handel i zapasy. ${ }^{34}$ Jak pokazują badania FAO, dla wielu państw handel stanowi główny

${ }^{29}$ Szerzej: FAO, Global Information and Early Warning System on Food and Agriculture, URL: <http://www.fao.org/giews/english/index.htm>, [dostęp 17.09.2013].

${ }^{30}$ Information for Decision-making in Food Security, An FAO/WFP briefing note on key global food security in information initiatives, Rome 2012, s. 6.

${ }^{31}$ L. Weingärtner, The Concept of Food and Nutrition Security, [w:] Achieving Food Security and Nutrition Security. Actions to Meet the Global Challenge. A Training Course Reader, red. K. Klennert, Bonn 2005, s. 5.

${ }^{32}$ The Economist, Global Food Security Index 2012, s. 15, URL: <http://foodsecurityindex. eiu.com/Home/DownloadMethodology>, [dostęp 6.03.2013].

${ }^{33}$ Szerzej: H. Ch. J. Godfray i in., The future of the global food system, "Philosophical Transactions of The Royal Society B” 2010, vol. 365, nr 1554, s. 2769-2777.

${ }^{34}$ Szerzej: K. Marzęda-Młynarska, Globalne zarządzanie, op. cit., s. 216-260. 
element polityki żywnościowej, pomagający niwelować okresowe wahania produkcji spowodowane np. przez zmiany klimatu. Do najważniejszych problemów w jego obszarze zalicza się: brak rynków, brak dostępu do rynków, brak infrastruktury transportowej i zaplecza technicznego do przechowywania żywności, wysokie koszty transakcyjne, brak dostępu do informacji o rynkach i kontrahentach, oraz brak dostępu do usług finansowych związanych z handlem. ${ }^{35}$ Podstawowym problemem w obszarze zapasów jest brak promocji tego typu rozwiązań oraz systemów zapewniających ich tworzenie na różnych szczeblach. ${ }^{36}$ Biorąc jednak pod uwagę specyfikę fizycznej dostępności żywności, a przede wszystkim sposób jej produkcji koncepcja zarządzania ryzykiem znajduje zastosowanie przede wszystkim w odniesieniu do oddziałujących na jej poziom zmian klimatu.

Nie ma jednoznacznej i powszechnie zaakceptowanej definicji zmian klimatu. ${ }^{37}$ Według Międzyrządowego Zespołu ds. Zmian Klimatu (Intergovernmental Panel on Climate Change - IPCC) pojęcie to odnosi się do zmiany jego stanu, o której świadczy zmiana charakterystycznych dla niego wartości średnich i/lub zmiana jego właściwości, utrzymująca się przez dłuższy czas zazwyczaj dekadę lub dłużej. Ich źródłem według IPCC mogą być naturalne procesy wewnętrzne lub siły zewnętrzne, ale także uporczywe antropogeniczne zmiany składu atmosfery. ${ }^{38}$ Bez względu na sposób definiowania, zmiany klimatu przejawiają się poprzez zespół obserwowalnych zjawisk. Za najważniejsze zagrożenia związane ze zmianami klimatu uznaje się: 1/obniżenie zdolności do regeneracji ekosystemów; 2/ wymieranie roślin i zwierząt; 3/spadek bioróżnorodności i zaopatrzenia w wodę i żywność; 4/ niszczenie obszarów nadbrzeżnych; 5/powodzie w następstwie podniesienia poziomu morza; 6/wzrost częstotliwości ekstremalnych zjawisk pogodowych oraz 7/pogorszenie stanu zdrowia ludzi w efekcie niedożywienia, zjawisk ekstremalnych czy przesuwania granicy występowania chorób, takich jak np. malaria. ${ }^{39}$ Za najbardziej zagrożone uznaje się te obszary, które ze względu na zmiany klimatu mogą zostać pozbawione podstaw egzystencji, czyli suche regiony w umiarkowanych i zwrotnikowych szerokościach geograficznych, regiony zależne od topnienia lodu, regiony $\mathrm{w}$ niskich szerokościach geograficznych ze względu na ryzyko braku wody i związanego z nim niedoboru żywności, a także

${ }^{35}$ Mission 2014: Feeding the World, Inadequate Food Distribution Systems, URL: $<$ http://12.000.scripts.mit.edu/mission2014/problems/inadequate-food-distribution-systems $>$, [dostęp 1.04.2013]. Zobacz też: World Hunger Series, op. cit.m s. 10.

${ }^{36}$ Szerzej na ten temat: K. Marzęda-Młynarska, Globalne zarządzanie, op. cit.,

${ }^{37}$ M. Pietraś, Międzynarodowy reżim zmian klimatu, Wydawnictwo A. Marszałek, Toruń 2011, s. 69.

${ }^{38}$ IPCC 2007, Zmiana Klimatu 2007. Raport Syntetyczny. Wklad Grup roboczych I, II i III do Czwartego Raportu Oceniajacego Międzyrządowego Zespołu ds. Zmian Klimatu, red. Główny Zespół Autorski, R.K. Pachauri, A. Reisinger, Warszawa 2009, s. 30; IPCC 2012, Managing the Risks of Extreme Events and Disasters to Advance Climate Change Adaptation. Special Report of the Intergovernmental Panel on Climate Change, red. Ch.B Filed i in., Cambridge 2012, s. 5.

${ }^{39}$ IPCC 2007, Zmiana Klimatu 2007. Raport Syntetyczny, s. 48-51. 
nisko położone obszary przybrzeżne, ze względu na ryzyko zatopienia i ekstremalne zjawiska pogodowe. ${ }^{40}$

W obliczu narastających zmian klimatu na znaczeniu zyskują działania służące adaptacji i odpowiedniemu przygotowaniu na ich skutki. Praktycznym przejawem zastosowania koncepcji zarządzania ryzykiem w tym obszarze jest zarządzanie ryzykiem katastrof $i$ adaptacja. Ich istotą jest $z$ jednej strony, gotowość na wypadek katastrofy, z drugiej zaś redukcja katastrof, gdzie pod pojęciem katastrofy rozumie się sytuację lub zdarzenie, które wiąże się z poważnymi i rozległymi zakłóceniami życia w społeczności lub wspólnocie, których większość ludzi nie jest w stanie przezwyciężyć bez wsparcia spoza danej wspólnoty lub społeczności, wymagające pomocy ze szczebla narodowego lub międzynarodowego, często nieprzewidywalne i nagłe, skutkujące wielkimi zniszczeniami i cierpieniem ludzi ${ }^{41}$ Samo zarządzanie ryzykiem katastrof $i$ adaptacja rozumiane są natomiast, jako proces ograniczania wpływu związanych z klimatem zagrożeń naturalnych, opierający się na ich prewencji, łagodzeniu i gotowości, oraz szeregu działań obejmujących świadomość ryzyka i jego analizę, upowszechnianie wiedzy, tworzenie polityk i legislację, budowę systemów wczesnego ostrzegania. ${ }^{42}$

Proces zarządzania ryzykiem katastrof obejmuje fazę analityczną i decyzyjną. $\mathrm{W}$ fazie analitycznej dokonuje się oceny prawdopodobieństwa określonych zdarzeń i skali ich potencjalnych skutków. Składają się na nie cztery typy zadań: 1/identyfikacja istoty, lokalizacji, intensywności i prawdopodobieństwa zagrożenia, 2/określenie poziomu wrażliwości i ekspozycji na zagrożenie, 3/identyfikacja zasobów i zdolności dostępnych do zajęcia się zagrożeniem, 4/określenie akceptowalnego poziomu ryzyka. Kluczowym elementem analizy zagrożeń jest prezentacja wyników, czemu służą mapy, prezentujące np. ryzyko zagrożenia powodzią czy suszą. ${ }^{43}$

$\mathrm{Na}$ fazę decyzją składa się zarówno kontekst podmiotowy jak i przedmiotowy. W przypadku wymiaru podmiotowego zakłada się, że 'administrowanie' ryzykiem stanowi domenę rządów, ale istotną rolę odgrywają w nim także inne podmioty, zlokalizowane na różnych szczeblach decyzyjnych. W wymiarze przedmiotowym, w ramach fazy decyzyjnej podejmuje się decyzje dotyczące: instytucjonalnego zaplecza ograniczania ryzyka katastrof, realizowanych polityk w tym obszarze, narodowych procesów planowania, planów redukcji ryzyka, czy ograniczeń systemowych $\mathrm{w}$ obszarze redukcji ryzyka. ${ }^{44}$

${ }^{40}$ Ibidem, s. 52.

${ }^{41}$ K. Vincent, T. Tanner, S. Devereux, Climate Change, Food Security and Disaster Risk Management, Issues paper for the Expert Meeting on Climate Change and Disaster Risk Management, FAO, Rome, 28-29 February 2008, s. 16. Zobacz też: M. Turnbull, C. L. Sterrett, A. Hilleboe, Toward Resilience. A Guide to Disaster Risk Reduction and Climate Change Adaptation, Practical Action Publishing 2013, s. 2.

${ }^{42}$ UN/ISDR, Living with Risk. A Global Review of Disaster Reduction Initiatives, Volume I, United Nations, New York, Geneva 2004, s. 17.

${ }^{43}$ Ibidem, s. 63-69.

${ }^{44}$ Ibidem, s. 80. 
Na gruncie zarządzania ryzykiem katastrof wykorzystywane są różne mechanizmy i instrumenty. Autorzy raportu Living with Risk. A Global Review of Disaster Reduction Initiatives zaliczają do nich: zarządzanie środowiskiem naturalnym, planowanie przestrzenne, bezpieczne budownictwo i ochronę krytycznych obiektów, narzędzia finansowe i gospodarcze (instrumenty finansowe na rzecz redukcji ryzyka katastrof na szczeblu narodowym, ubezpieczenia) oraz systemy wczesnego ostrzegania. ${ }^{45}$

Podstawową rolę w przypadku adaptacji do zmian klimatu i redukcji ryzyka katastrof przypisuje się strategii akceptacji i unikania ryzyka, polegającej, z jednej strony, na zdolności do reagowania i dostosowania się do rzeczywistych lub potencjalnych skutków zmian klimatu w taki sposób by minimalizować szkody lub korzystać z wszelkich pozytywnych możliwości, które mogą wiązać się z klimatem (adaptacja). ${ }^{46} \mathrm{Z}$ drugiej zaś, zmniejszaniu ryzyka katastrof przez systematyczną analizę i zarządzanie czynnikami katastrof, zmniejszanie ekspozycji na zagrożenie, zmniejszenie wrażliwości ludzi i mienia a także odpowiedniego zarządzania ziemią, środowiskiem naturalnym oraz zwiększeniem gotowości W obliczu niepożądanych zdarzeń (redukcja ryzyka katastrof). ${ }^{47}$

W wymiarze praktycznym podstawę implementacji strategii redukcji ryzyka katastrof $i$ adaptacji do zmian klimatu stanowią Ramy Działania Hyogo (The Hyogo Framework for Action) przyjęte podczas Światowej Konferencji Redukcji Katastrof, która odbyła się w 2005 roku w Kobe w Japonii. U podstaw ich przyjęcia legło przekonanie o konieczności promocji bardziej zintegrowanego podejścia do redukcji ryzyka związanego z obecną zmiennością klimatu i przyszłymi zmianami klimatu. Oparto je na pięciu priorytetach, do których zaliczono: uznanie redukcji ryzyka katastrof za priorytet na szczeblu lokalnym i narodowym wraz z zabezpieczeniem bazy instytucjonalnej jego implementacji, identyfikację, ocenę i monitorowanie ryzyka katastrof $i$ wzmocnienie wczesnego ostrzegania, wykorzystanie wiedzy i innowacji do adaptacji do ryzyka, ograniczenie podstawowych czynników ryzyka, wzmocnienie gotowości dla efektywnych działań wobec katastrof na każdym ze szczebli zarządzania. Za podstawowe instrumenty redukcji ryzyka i adaptacji w obszarze bezpieczeństwa żywnościowego uznano: dywersyfikację upraw, wprowadzenie systemów ubezpieczeń na wypadek utraty zbiorów, wprowadzanie nowych odmian roślin bardziej odpornych na ekstremalne zjawiska pogodowe, zmianę czasu sadzenia roślin, zmianę wykorzystania terenów uprawnych. ${ }^{48}$

Uznaje się, że promocja strategii redukcji ryzyka katastrof i adaptacji do zmian klimatu zwiększa odporność populacji wysokiego ryzyka a także, służy ochronie i wzmocnieniu lokalnych ekosystemów oraz rozwoju zasobów ludzkich

${ }^{45}$ Ibidem, s. 297.

${ }^{46}$ K. Vincent, T. Tanner, S. Devereux, Climate Change, op. cit., s. 16.

${ }^{47}$ M. Turnbull, C. L. Sterrett, A. Hilleboe, Toward Resilience, op. cit., s. 2.

${ }^{48}$ Szerzej: ISDR, Climate Change and Disaster Risk Reduction, Brifing Note 01, Geneva, September 2008, s. 8 . 
w celu zmniejszenia wrażliwości. Zalecane działania na rzecz redukcji ryzyka katastrof $i$ adaptacji do zmian klimatu w obszarze bezpieczeństwa żywnościowego prezentuje tabela 2 .

Tab. 2. Zalecane działania na rzecz redukcji ryzyka katastrof $i$ adaptacji do zmian klimatu w obszarze bezpieczeństwa żywnościowego

\begin{tabular}{|c|c|}
\hline Zadanie & Dzialania \\
\hline $\begin{array}{l}\text { 1. Podniesienie } \\
\text { świadomo- } \\
\text { ści zagrożeń } \\
\text { i zmian klimatu }\end{array}$ & $\begin{array}{l}\text { - Badania rolnictwa w celu lepszego zrozumienia obecnych i prognozowanych } \\
\text { zagrożeń związanych ze zmianami klimatu } \\
\text { - Wspieranie tworzenia map rozwoju klimatu i ryzyka katastrof a także planów } \\
\text { działania na różnych poziomach zarządzania } \\
\text { - Wspieranie tworzenia lokalnych centrów informacji i edukacji na temat za- } \\
\text { grożeń, prognoz, map zamian klimatu i zagrożeń katastrofami }\end{array}$ \\
\hline $\begin{array}{l}\text { 2. Podniesienie } \\
\text { świadomości } \\
\text { ekspozycji, } \\
\text { wrażliwości } \\
\text { i zdolności }\end{array}$ & $\begin{array}{l}\text { - Identyfikacja stopnia ekspozycji źródeł zaopatrzenia w żywność, mechani- } \\
\text { zmów jej nabywania i infrastruktury na zagrożenia związane ze zmianami } \\
\text { klimatu } \\
\text { - Przeprowadzania analizy zdolności uczestnictwa i wrażliwości na poziomie } \\
\text { lokalnym w celu lepszego zrozumienia przez zagrożone społeczności powią- } \\
\text { zań pomiędzy ich bezpieczeństwem żywnościowym a zmianami klimatu i ka- } \\
\text { tastrofami } \\
\text { - Wykorzystanie różnych metod w celu pogłębienia świadomości zakresu czyn- } \\
\text { ników wpływających na bezpieczeństwo żywnościowe społeczności ryzyka } \\
\text { i ich związków z katastrofami i zmianami klimatu } \\
\text { - Podniesienie (poprzez edukację, szkolenia) świadomości w społecznościach } \\
\text { ryzyka roli kobiet w rolnictwie i systemach żywnościowych }\end{array}$ \\
\hline $\begin{array}{l}\text { 3. Uznanie praw } \\
\text { i obowiązków }\end{array}$ & $\begin{array}{l}\text { - Podniesienie rangi katastrof i zmian klimatu w obszarze bezpieczeństwa żyw- } \\
\text { nościowego, poprzez kampanie podnoszenia świadomości, lobbowanie wśród } \\
\text { zainteresowanych stron rządowych i rzecznictwo wśród międzynarodowych } \\
\text { darczyńców / fundatorów, w celu zwiększenia zapotrzebowania na 'inteligent- } \\
\text { ne klimatycznie' inwestycje i zarządzanie bezpieczeństwem żywności } \\
\text { - Wykorzystanie popularnych mediów i tradycyjnych kanałów komunikacji } \\
\text { w celu podniesienia świadomości gospodarstw domowych związków pomię- } \\
\text { dzy zmianami klimatu, wykorzystaniem surowców naturalnych i bezpieczeń- } \\
\text { stwem żywnościowym } \\
\text { - Popieranie realizacji prawa kobiet i osób marginalizowanych do kluczowych } \\
\text { zasobów (ziemia, woda) poprzez kampanie podnoszenia świadomości, usta- } \\
\text { wodawstwo, a także bezpośrednie wsparcie dla organizacji zajmujących się tą } \\
\text { problematyką }\end{array}$ \\
\hline $\begin{array}{l}\text { 4. Wzmocnienie } \\
\text { udziału społe- } \\
\text { czeństw ryzyka }\end{array}$ & $\begin{array}{l}\text { - Wspieranie budowy/rozwoju kanałów (radio), poprzez które rozpowszechnia- } \\
\text { ne są lokalne informacje o klimacie i zagrożeniach z nim związanych } \\
\text { - Wspieranie systemu informacji rynkowych (ceny, standardy, produkty) na po- } \\
\text { ziomie lokalnym } \\
\text { - Współpraca ze szczególnie zagrożonymi producentami żywności (kobiety, } \\
\text { ludność marginalizowana) w celu podniesienia wydajności poprzez wzmoc- } \\
\text { nienie ich prawa do ziemi i wody, zwiększenia dostępności do rynku, środków } \\
\text { finansowych i ubezpieczeń } \\
\text { - Prowadzenie szkoleń dla rolników, dotyczących odpowiedzialnego rolnictwa, } \\
\text { przeciwdziałania degradacji gleb, bioróżnorodności } \\
\text { - Szkolenia dla grup w ramach społeczeństw ryzyka dotyczących domowych } \\
\text { strategii odżywiania w kontekście zmian klimatu i ryzyka katastrof }\end{array}$ \\
\hline
\end{tabular}




\begin{tabular}{|c|c|}
\hline $\begin{array}{l}\text { 5. Wspieranie } \\
\text { systemowego } \\
\text { zaangażowania } \\
\text { i zmiany }\end{array}$ & $\begin{array}{l}\text { - Tworzenie polityk dotyczących bezpieczeństwa żywnościowego, ochrony } \\
\text { zdrowia, rolnictwa i rozwoju gospodarczego w oparciu o analizę ryzyka kata- } \\
\text { strof i zmian klimatu } \\
\text { - Promowanie inwestycji na rzecz budowy systemów zabezpieczeń społecz- } \\
\text { nych uwzględniających zagrożenia dla bezpieczeństwa żywnościowego } \\
\text { - Promowanie koordynacji pomiędzy NGOs działających w obszarze bezpie- } \\
\text { czeństwa żywnościowego, zdrowia, ubóstwa, w celu stworzenia holistycz- } \\
\text { nych strategii dotyczących ryzyka katastrof i zmian klimatu }\end{array}$ \\
\hline $\begin{array}{l}\text { 6. Wspieranie } \\
\text { synergii pomię- } \\
\text { dzy różnymi } \\
\text { poziomami }\end{array}$ & $\begin{array}{l}\text { - Wskazanie narodowych polityk i przepisów dotyczących bezpieczeństwa } \\
\text { żywnościowego, zmian klimatu i ryzyka katastrof w celu ich implementacji } \\
\text { w społecznościach wysokiego ryzyka } \\
\text { - Wspieranie budowy wielopoziomowych systemów monitorowania bezpie- } \\
\text { czeństwa żywnościowego i planowania ewentualnościowego }\end{array}$ \\
\hline $\begin{array}{l}\text { 7. Tworzenie } \\
\text { i wykorzysty- } \\
\text { wanie różnych } \\
\text { źródeł wiedzy }\end{array}$ & $\begin{array}{l}\text { - Wspieranie rozwoju systemów wzmacniających dostęp producentów żywno- } \\
\text { ści od informacji o klimacie i pogodzie } \\
\text { - Organizowanie platform współpracy i wymiany informacji o zmianach klima- } \\
\text { tu i ryzyku katastrof pomiędzy producentami żywności, ekspertami z zakresu } \\
\text { bezpieczeństwa żywnościowego oraz ekspertami ds. zmian klimatu i katastrof } \\
\text { - Tworzenie projektów wspierających innowacje, adresowanych do drobnych } \\
\text { producentów żywności, dostawców technologii i instytucji badawczych } \\
\text { - Zachęcanie społeczności wysokiego ryzyka do odkrywania i wykorzystywa- } \\
\text { nia tradycyjnych sposobów zapewniania bezpieczeństwa żywnościowego (np. } \\
\text { banki nasion) }\end{array}$ \\
\hline $\begin{array}{l}\text { 8. Promocja } \\
\text { elastyczności } \\
\text { i responsyw- } \\
\text { ności }\end{array}$ & $\begin{array}{l}\text { - Współpraca z przedstawicielami rządu na różnych poziomach w celu two- } \\
\text { rzenia rezerw żywności oraz funduszy wczesnego wsparcia w sytuacji braku } \\
\text { bezpieczeństwa żywnościowego spowodowanego zmianami klimatu } \\
\text { - Wspieranie dostępu lokalnych i regionalnych instytucji rządowych do global- } \\
\text { nych narzędzi gromadzenia i upowszechnia informacji }\end{array}$ \\
\hline $\begin{array}{l}\text { 9. Zwrócenie } \\
\text { uwagi na różne } \\
\text { poziomy }\end{array}$ & $\begin{array}{l}\text { - Włączenie wskaźników wczesnego ostrzegania w obszarze bezpieczeństwa } \\
\text { żywnościowego w systemy monitorowania } \\
\text { - Wspieranie gospodarstw domowych i wspólnot w działaniach przygotowaw- } \\
\text { czych tj. przechowywanie żywności, szczepienie zwierząt, oszczędzanie i mi- } \\
\text { kro ubezpieczenia } \\
\text { - Wspieranie rozwoju ukierunkowanych badań w obszarze bezpieczeństwa } \\
\text { żywnościowego w celu lepszego planowania i adaptacji do zmian klimatu } \\
\text { i ryzyka katastrof } \\
\text { - Ocena zgodności narodowych strategii i polityk w obszarze bezpieczeństwa } \\
\text { żywnościowego ze scenariuszami ryzyka (mocne strony, słabe strony) i ich } \\
\text { rewizja pod kątem przygotowania na ryzyko katastrof i zmiany klimatu } \\
\text { - Wspieranie społeczności wysokiego ryzyka w dostępie do systemów mikro } \\
\text { ubezpieczeń }\end{array}$ \\
\hline $\begin{array}{l}\text { 10. Minimalizo- } \\
\text { wanie szkód }\end{array}$ & $\begin{array}{l}\text { - Analizowanie wpływu pomocy żywnościowej udzielanej w sytuacji kryzyso- } \\
\text { wej na lokalne rynki żywności i ceny żywności } \\
\text { - Rozpatrywanie programów transferu gotówki i gotówka za żywność jako } \\
\text { środków ochrony społeczności pozbawionych bezpieczeństwa żywnościowe- } \\
\text { go przy jednoczesnym wsparciu dla lokalnych producentów żywności i do- } \\
\text { stawców }\end{array}$ \\
\hline
\end{tabular}

Źródło: M. Turnbull, C. L. Sterrett, A. Hilleboe, Toward Resilience. A Guide to Disaster Risk Reduction and Climate Change Adaptation, Practical Action Publishing 2013, s. 49-52. 


\section{ZARZĄDZANIE RYZYKIEM W OBSZARZE EKONOMICZNEJ DOSTĘPNOŚCI ŻYWNOŚCI}

Ekonomiczna dostępność żywności oznacza, że każda jednostka i gospodarstwo domowe posiada wystarczające zasoby pozwalające nabyć żywność w odpowiedniej ilości i jakości. ${ }^{49}$ Składają się na nie zasoby finansowe (gotówka, oszczędności, cenne rzeczy), zasoby ludzkie (umiejętności, wiedza, dobre zdrowie), zasoby naturalne (ziemia, woda), zasoby fizyczne (infrastruktura, narzędzia, maszyny, wyposażenie itp.) oraz zasoby społeczne (zaufanie, normy i wartości warunkujące relacje międzyludzkie). ${ }^{50}$ Umożliwiają one nabycie żywności w sposób bezpośredni, poprzez jej produkcję lub pośredni, poprzez wymianę. Im większe i bardziej 'płynne' zasoby, tym większy ekonomiczny dostęp do żywności.

Istota ekonomicznej dostępności żywności wyraża się poprzez 'wystarczalność' zasobów. W jaki jednak sposób ową 'wystarczalność' mierzyć, lub inaczej w stosunku do czego? Bez wątpienia analiza ekonomicznej dostępności żywności musi uwzględniać także jej ceny. Dopiero dzięki zestawieniu obu wielkości - cen i zasobów, możemy ustalić czy jest ona (czy nie) ekonomicznie dostępna. ${ }^{51} \mathrm{Co}$ ciekawe, brak ekonomicznej dostępności żywności jest w takim samym stopniu warunkowany wysokimi, jak i niskimi cenami. Wysokie ceny wpływają na poziom konsumpcji i dochody konsumentów, oznaczają, że więcej zasobów trzeba przeznaczyć na jej zakup. Niskie są zagrożeniem dla produkcji i dochodów producentów, oznaczają mniejsze wpływy ze sprzedaży i mniejsze zyski.

Głównym problemem identyfikowanym w obszarze ekonomicznej dostępności żywności jest bez wątpienia duża zmienność cen oraz towarzyszące jej tzw. skoki cenowe. Na przełomie XX i XXI wieku doszło do nich dwukrotnie w 2008 i 2011 roku. Ich efektem było zarówno pogorszenie stanu bezpieczeństwa żywnościowego na świecie, jak i znaczne osłabienie szans państw rozwijających się na wzrost gospodarczy i redukcję ubóstwa. ${ }^{52}$ Ponieważ duża dynamika cen żywności w największym stopniu wpływa na sytuację ekonomiczną i poziom bezpieczeństwa żywnościowego państw uzależnionych od jej importu, koncepcja zarządzania ryzykiem wykorzystywana jest przede wszystkim jako sposób minimalizacji negatywnych skutków ryzyka zmienności cen żywności.

Szczególna przydatność koncepcji zarządzania ryzykiem w tym obszarze wynika głównie z nieprzewidywalności czynników kształtujących poziom cen. Składają się na nie gra popytu i podaży, warunki pogodowe, wzrost liczby ludności, wzrost gospodarczy w regionach o wysokiej populacji, katastrofy naturalne,

${ }^{49}$ L. Weingärtner, The Concept of Food and Nutrition Security, op. cit., s. 5.

${ }^{50}$ World Hunger Series, op. cit., s. 57.

${ }^{51}$ K. Marzęda-Młynarska, Globalne zarzadzanie, op. cit., s. 260-289.

${ }^{52}$ Szerzej patrz: CFS/HLPE, Price Volatility and Food Security. A Report of the High Level Panel of Experts on Food Security and Nutrition, Rome 2011; C. L. Gilbert, C. W. Morgan, Food price volatility, "Philosophical Transactions of The Royal Society B" 2010, vol. 365, nr 1554, s. 3023-3034. 
kryzysy, konflikty, oraz produkcja biopaliw. Praktycznym przejawem jej wykorzystania jest eksternalizacja ryzyka, poprzez stosowanie instrumentów rynkowych. A więc, trzymając się ogólnych założeń, przeniesienie ryzyka na rynek za pośrednictwem instrumentów finansowych, pozwalających na minimalizację ewentualnych kosztów zmian cen żywności, zarówno po stronie konsumentów, jak i producentów.

Na strategię eksternalizacji ryzyka zmienności cen żywności składają się cztery elementy. Pierwszy dotyczy wyboru instrumentów, określenia wielkości kontraktu i horyzontu czasowego. W drugim, określa się procedury i podmioty odpowiedzialne za realizację strategii, w trzecim - dokonuje wyboru kontrahenta, w czwartym zaś - realizuje strategie. ${ }^{53}$

Przeprowadzona przez ekspertów FAO i Morgan Stanley Commodities Group analiza wskazuje, że strategia eksternalizacji ryzyka, znana i wykorzystywana przez prywatne przedsiębiorstwa, może być z powodzeniem stosowana również przez rządy państw, bez względu na to, czy są producentami żywności i starają się chronić swoje dochody z eksportu, czy też importerami, starającymi się zabezpieczyć krajowych konsumentów. ${ }^{54}$ Strategia opiera się na wykorzystaniu instrumentów finansowych zwanych derywatami, których wartość jest ściśle związana $\mathrm{z}$ wartością dobra (produkty żywnościowe) powiązanego z tym instrumentem i polega na zawieraniu jednocześnie dwóch transakcji: rzeczywistej, kiedy dochodzi do faktycznego zakupu danego dobra i nierzeczywistej, służącej zabezpieczeniu przed wahaniami cen tego dobra. Do najczęściej stosowanych przez państwa instrumentów zarządzania ryzykiem należą swapy ${ }^{55} \mathrm{i}$ opcje ${ }^{56}$.

Badania wskazują, że zastosowanie strategii przeniesienia ryzyka na rynek w dużym stopniu chroni importerów i eksporterów przed nieprzewidywalnymi zmianami (skokami) cen żywności. Jednak, jak zauważają eksperci z Morgan Stanley Commodities Group, jest ona w niewielkim stopniu wykorzystywana przez

${ }^{53}$ Morgan Stanley Commodities Group, Using risk management tools to manage price volatility in food import: practice, [w:] Safeguarding food security in volatile global markets, red. A. Prakash, FAO, Rome 2011, s. 405-422-425.

${ }^{54}$ Ibidem, s. 405-429.

${ }^{55}$ Swap to kontrakt oparty na cenie danego towaru, który zawiera zobowiązanie do kupna lub jego sprzedaży w określonym czasie. Zawierając taki kontrakt strona ustala cenę za jaką jest gotowa dane dobro sprzedać lub kupić. W sytuacji gdy cena jest niższa niż ustalona, płaci różnicę kontrahentowi, jednocześnie dokonując rzeczywistego zakupu dobra po ustalonej cenie. W przypadku zwyżki cen inkasuje różnicę od kontrahenta, także dokonując zakupu po ustalonej cenie. W obu przypadkach ryzyko wahań cenowych zostaje przeniesione na rynek.

${ }^{56}$ Istota opcji zawiera się w prawie do zakupu lub sprzedaży danego dobra po określonej cenie w określonym czasie. Celem opcji jest zabezpieczenie ceny dobra, bowiem jej właściciel ma trzy możliwości, może wykonać opcję (zrealizować), pozwolić jej wygasnąć, lub odsprzedać. Wykonanie opcji następuje zazwyczaj w sytuacji kiedy cena towaru w niej określona jest niższa niż w momencie jej wykonania. Pozwala to ich posiadaczom ubezpieczyć się na wypadek zwyżki cen. Co więcej, ponieważ posiadacz opcji posiada prawo a nie obowiązek dokonania transakcji, sam dokonuje oceny opłacalności jej wykonania. 
państwa, szczególnie te uzależnione od jej importu. Barierą, ich zdaniem, może być niewłaściwe rozumienie działania instrumentów pochodnych, obawy przed związaniem się niekorzystną transakcją, biurokracją czy koszty związane z realizacją całej operacji ${ }^{57} \mathrm{Nie}$ zmienia to jednak faktu, że w perspektywie niekorzystnych prognoz dotyczących cen żywności, może być postrzegana, jako jedna $z$ bardziej skutecznych metod zabezpieczenia się przed ryzykiem szoków cenowych.

\section{ZARZĄDZANIE RYZYKIEM W OBSZARZE ZDROWOTNEJ JAKOŚCI ŻYWNOŚCI}

Zdrowotna jakość żywności oznacza, że każda jednostka i gospodarstwo domowe ma dostęp do żywności o właściwej wartości odżywczej oraz spełniającej odpowiednie standardy, zapewniającej zdrowe i aktywne życie. Przy czym przez 'właściwą wartość odżywczą żywności należy rozumieć odpowiedni poziom kalorii i mikroelementów per capita, natomiast przez bezpieczeństwo żywności (food safety) - brak zanieczyszczeń i substancji mogących zagrażać zdrowiu i życiu człowieka. ${ }^{58}$

Ze względu na istniejącą integrację i globalizację rynków, a także zmiany w produkcji i dystrybucji, zapewnienie zdrowotnej jakości żywności wiąże się przede wszystkim z bezpieczeństwem żywności. WHO (Światowa Organizacja Zdrowia) wyodrębnia cztery główne problemy w tym obszarze: rozprzestrzenianie się zagrożeń mikrobiologicznych, skażenia chemiczne, wyzwania związane z nowymi technologiami (GMO) oraz funkcjonowanie systemów bezpieczeństwa żywności. ${ }^{59}$

Rosnąca skala zagrożeń oraz tempo ich rozprzestrzenia wymusza zastosowanie metod pozwalających na antycypowanie ich wystapienia i konsekwencji, dlatego tak szerokie zastosowanie na gruncie zdrowotnej jakości żywności ma koncepcja zarządzania ryzykiem, której podstawowym celem jest tu ochrona zdrowia publicznego, poprzez kontrolę ryzyk związanych z jej produkcją, dystrybucją i konsumpcją ${ }^{60}$ Praktycznym przejawem jej zastosowania jest działalność powołanej wspólnie przez FAO i WHO Komisji Kodeksu Żywnościowego (Codex Alimenatarius Commission). Należy bowiem podkreślić, że analiza ryzyka stanowi podstawową metodologię leżącą u podstaw opracowanych w jej ramach standardów bezpieczeństwa żywności ${ }^{61}$, zapewniających ochronę konsumentów oraz tworzących ramy handlu żywnością.

\footnotetext{
${ }^{57}$ Ibidem, s. 407-408.

${ }^{58}$ Szerzej: K. Marzęda-Młynarska, Globalne zarzadzanie, op. cit., s. 290-316.

${ }^{59}$ WHO, Ten Facts on Food Security, October 2009, URL: <http://www.who.int/features/ factfiles/food_safety/en/index.html>, [dostęp 25.03.2013].

${ }^{60}$ Risk Management and Food Safety, op. cit., s. 3. Zob. też: L. N. Jackson, M. Jansen,

${ }^{61}$ K. Marzęda-Młynarska, Globalne zarządzanie, op. cit., s. 484-487.
} op. cit., s. 538-547. 
Wyrazem tego są zalecenia ujęte w ramach Codex Alimenatarius Commission Procedural Manual 2015, zgodnie z którymi proces zarządzania ryzykiem w obszarze zdrowotnej jakości żywności, powinien składać się z trzech faz: analitycznej, decyzyjnej i komunikacyjnej ${ }^{62}$. Faza analityczna obejmuje identyfikację zagrożeń i ich charakterystykę oraz charakterystykę ryzyka i ocenę ekspozycji na nie. Faza decyzyjna służy przygotowaniu alternatywnych polityk ukierunkowanych na minimalizację ryzyka, ochronę zdrowia i promocję uczciwych zasad handlowych, a także, wdrażaniu odpowiednich instrumentów kontroli, łącznie z działaniami regulacyjnymi. Faza komunikacyjna ma charakter interaktywny i polega na wymianie informacji i opinii pomiędzy podmiotami dokonującymi oceny ryzyka, decydentami i innymi zainteresowanymi stronami (konsumenci, ośrodki badawcze, środowisko naukowe).$^{63}$

Ramy strategii zarządzania ryzykiem w obszarze zdrowotnej jakości żywności wyznaczają cztery etapy działań. Pierwszy stanowi ocena ryzyka. Na tym etapie dokonuje się identyfikacji problemu w obszarze bezpieczeństwa żywności, tworzy profil ryzyka, dokonuje hierarchizacji zagrożeń z punktu widzenia oceny i 'administrowania' ryzykiem, uruchamia proces oceny i analizuje rezultaty. Etap drugi to 'administrowanie' ryzykiem. Na tym etapie dokonuje się identyfikacji dostępnych opcji działan, dokonuje ich selekcji oraz podejmuje ostateczną decyzję. Trzeci etap to implementacja decyzji, natomiast czwarty to monitoring i przegląd, w ramach którego ocenia się skuteczność wdrożonych rozwiązań oraz ocenia celowość podjętych działań. ${ }^{64}$

Codex Alimenatarius Commission Procedural Manual 2015 określa również zasady, na których powinien opierać się proces zarządzania ryzykiem w obszarze zdrowotnej jakości żywności, do których należą: ustrukturalizowany przebieg (fazy, etapy), dążenie do ochrony zdrowia ludzkiego, transparencja, uczciwość naukowa i obiektywizm, komunikacja $\mathrm{z}$ konsumentami i innymi zainteresowanymi podmiotami, a także ciągły charakter i uwzględnianie nowych danych i wyników badań. ${ }^{65}$

Biorąc pod uwagę fakt, że zarządzanie ryzykiem w obszarze zdrowotnej jakości żywności stanowi podstawową metodę działania Komisji Kodeksu Żywnościowego a analiza ryzyka legła u podstaw przyjętych w jej ramach standardów, wytycznych i kodeksów postępowania, można uznać, że stanowi użyteczną i skuteczną metodę identyfikacji i kontroli zagrożeń w tym obszarze.

${ }^{62}$ Codex Alimentarius Commission, Procedural Manual, Twenty Third Edition, WHO/FAO, Rome 2015, s. 109.

${ }^{63}$ Ibidem, s. 116.

${ }^{64}$ Risk Management and Food Safety, op. cit., s. 5.

${ }^{65}$ Ibidem, s. 7. 


\title{
WNIOSKI
}

Przeprowadzona analiza daje podstawę do sformułowania następujących wniosków. Po pierwsze, koncepcja zarządzania ryzykiem, znajduje szerokie zastosowanie na gruncie bezpieczeństwa żywnościowego. Po drugie, głównym motywem jej wykorzystanie jest dążenie do jego zapewnienia. Po trzecie, strategie, mechanizmy i instrumenty minimalizacji ryzyka a także, skala zastosowania i stopień instytucjonalizacji zarządzania ryzykiem zależą od wymiaru bezpieczeństwa żywnościowego - największa skala i stopień instytucjonalizacji występuje w przypadku zdrowotnej jakości żywności i fizycznej dostępności żywności, najmniejsza - w przypadku ekonomicznej dostępności żywności. Po czwarte, zarządzanie ryzykiem, ma charakter perspektywiczny i wykazuje dużą użyteczność, jako metoda eliminacji i ograniczania ryzyk, szczególnie współzmiennych, w obszarze bezpieczeństwa żywnościowego.

\section{THE USE OF A RISK GOVERNANCE CONCEPT IN THE AREA OF FOOD SECURITY}

\begin{abstract}
The goal of the article is to analyze the use of the risk governance concept in the area of food security. The concept is treated as a method to ensure food security in both the positive sense (scenarios creation, early warning systems) and the negative sense (risk reduction). The analysis is organized around two problems: the main assumptions of the risk governance concept and the application of risk governance in the area of food security. The first part discusses risk governance is discussed as a theoretical concept. In the second part, the practical application of risk governance is discussed in the three dimensions of food security: food availability, food access and food safety. The analysis permits four conclusions: first, the concept of risk governance is widely used in the context of food security. Second, the main motive for its use is to strive to ensure food security. Third, strategies, mechanisms, and instruments to minimize the risk as well as the scale of application and the degree of institutionalization of risk governance depend on the food security dimension. Fourth, risk governance has a high usability as a process for elimination and mitigation of risks, particularly covariate ones, in the area of food security.
\end{abstract}

Key words: food security, risk governance. 